\title{
種結晶添加による多孔質窒化ケイ素の合成
}

\author{
稲垣良昭·安藤元英·大司達樹* \\ ファインセラミックス技術研究組合シナジーセラミックス研究所, 463-8687 名古屋市守山区下志段味字穴ヶ洞 2268-1 \\ *産業技術総合研究所シナジーーテリアル研究センター，463-8687 名古屋市守山区下志段味字穴ヶ洞 2268-1

\section{Synthesis of Porous Silicon Nitride by Using Seed Crystals} \\ Yoshiaki INAGAKI, Motohide ANDO and Tatsuki OHJI* \\ Synergy Ceramics Laboratory, Fine Ceramic Research Association, Shimo-Shidami, Moriyama-ku, Nagoya-shi 463-8687 \\ * Synergy Materials Research Center, National Institute of Advanced Industrial Science and Technology, \\ Shimo-Shidami, Moriyama-ku, Nagoya-shi 463-8687
}

\begin{abstract}
Synthesis of porous silicon nitride $\left(\mathrm{Si}_{3} \mathrm{~N}_{4}\right)$ by using seed crystals was studied. Seed crystals were prepared by heating a powder mixture of $\alpha-\mathrm{Si}_{3} \mathrm{~N}_{4}$ and sintering aids. $\mathrm{Y}_{2} \mathrm{O}_{3}$ was the most effective additive for obtaining seed crystals of high aspect ratio. By adding rod-like seed crystals to $\alpha=\mathrm{Si}_{3} \mathrm{~N}_{4}$ starting powder, porous $\mathrm{Si}_{3} \mathrm{~N}_{4}$ with relatively high porosity could be fabricated. In the case of adding 50 vol\% seed crystal, rod-like grains were well combined, forming a framework. The effect of sintering additives on porosity of the porous body was also studied. By adding 5 mass $\% \mathrm{Y}_{2} \mathrm{O}_{3}$ and 2 mass $\% \mathrm{Al}_{2} \mathrm{O}_{3}$ as sintering additives, the porosity of sintered body was reduced. [Received May 24, 2001; Accepted August 9, 2001]
\end{abstract}

Key-words : Silicon nitride, Seed crystal, Fibrous grain, Porous body

\section{1. 緒 言}

超高温ガスタービン等の構造部材としてのセラミックスの信 頼性を確保するためには，破断歪みを増大させるとともに，損 傷許容性を含めた高勒性化が必要である。従来，破断ひずみの 増大は強度を向上させることにより実現されてきた。しかし， その強度特性は製造プロセス中に導入される欠陷寸法とばらつ きに強く依存する。このため，強度の向上を図るためには製造 プロセスを厳密に制御することにより欠陷導入を抑制すること が必要となる。一方, 弾性率の観点から考えると, 強度を維持 したまま弾性率を低下させることができれば，破断ひずみを增 大させることができる. Shigegaki ら ${ }^{1), 2)}$ は，低弾性率層との 複合化を検討し，気孔を含む多孔質層を分散させた緻密質/多 孔質の多層構造を形成して評価を行い，弾性率の低減による破 断ひずみ增加の可能性を確認し，更に窒化ケイ素ウィスカーを 用いて柱状粒子を一方向へ配向させた組織の窒化ケイ素多孔体 が，その異方性気孔の配向によって応力に垂直な断面の有效欠 陥サイズが小さくできるので, 多孔質であっても強度低下の抑 制に有利な気孔構造であることを指摘している3)。また著者ら は，この窒化ケイ素多孔体の損傷許容性について評価を行い，

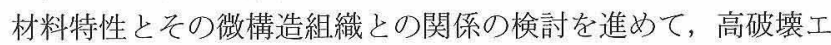
ネルギー発現のメカニズムに関する知見を得ている4).

しかし，柱状粒子を主体とする多孔構造を形成するために， 出発原料として用いているウイスカーは，現在，市場に拈ける 入手が非常に困難な状況であり，同原料の使用を回避すること が望ましい，そこで著者らは，出発原料としてウイスカーに類 似した形態を有する種結晶を候補として選択した。著者らの知 る限り，種結晶は緻密質窒化ケイ素の高勒化のために，粒成長 の核として微量を添加して用いるのみ5) -7)で，これを出発原料 として多孔体を作製した報告はなされていない，以上のことか ら，本研究ではウイスカーに類似した形態を有する種結晶を簡 便に作製して出発原料とするとともに，ウイスカーの替わりに この種結晶を適用して, 柱状粒子を主体とする多孔構造の形成 を試みた。

\section{2. 実 験}

\section{1 種結晶の作製及び評価}

ウイスカーの代替としての種結晶は，その形態として大きな アスペクト比を有することが必要であると考えられる．そこ で, 助阂成分と比表面積の異なる $\alpha$ 窒化ろイ素粉末を混合し て生成する種結晶の形態を調査し，種結晶の作製に適当である 出発原料の組み合わせの適正化を行った。

焼結助剂々して $\mathrm{Al}_{2} \mathrm{O}_{3}, \mathrm{CeO}_{2}, \mathrm{Y}_{2} \mathrm{O}_{3}$ の 3 種類を, $\alpha$ 窒化ケイ 素には比表面積の異なる 3 種類の粉末 (宇部興産製：SN-E03, SN-E05, SN-E10；此表面積はそれぞれ 3, 5, $10 \mathrm{~m}^{2} / \mathrm{g}$ ）を選 択して，それぞれを組み合わせて種結晶を作製した。助剤成分 を均一に分散させるために, $\mathrm{Al}_{2} \mathrm{O}_{3}, \mathrm{CeO}_{2}, \mathrm{Y}_{2} \mathrm{O}_{3}$ の成分を含む ゾル溶液 $\left(\mathrm{Al}_{2} \mathrm{O}_{3}, \mathrm{CeO}_{2}\right.$ ：日産化学工業製， $\mathrm{Y}_{2} \mathrm{O}_{3}$ : 多木化学製) を用いた．助剤の添加量を酸化物換算で $5 \mathrm{~mol} \%$ として，メタ ノ一ル溶媒で粉末と混合し, 真空エバポレーターによる乾燥, $\mathrm{N}_{2}+5 \% \mathrm{H}_{2}$ の混合ガス中で $800^{\circ} \mathrm{C}, 2 \mathrm{~h}$ の仮焼により脱脂を行っ た。続いて, 得られた混合粉末を圧粉しない状態で $1850^{\circ} \mathrm{C}, 2 \mathrm{~h}$, $0.5 \mathrm{MPa}$ の窒素䨌囲気の条件下で焼成を行った。得られた種 結晶の焼成体を粉砕して，200メッシュのふるい通しを行っ た、種結晶の作製プロセスの簢便化を図るため, Hirao ら ${ }^{8) か ゙ ~}$ 行った複雑な酸処理は行わなかった。得られた種結晶の形態は 走査型電子顕微鏡 (SEM) により観察した. 種結晶の観察像 から任意の 100 個の粒子を選択して，その粒子径の計測とアス ペクト比の算出を行った.

\section{2 多孔体の作製及び評価}

形態観察の結果から選択した種結晶を用いて，柱状粒子を主 体とする多孔構造を形成することを試みた。るず，種結晶の添 加量による焼成体の微構造への影響を調査するために, 助剤を 添加しないで $\alpha$ 窒化ケイ素（SN-E10）に種結晶をそれぞれ30 vol\%, 50 vol\%, 70 vol\%添加した。各粉末は 1.5 mass\%の分散 剂（花王製：レオガード GP）を添加したメタノール溶媒でそ れでれ混合して，真空エバポレーターによる乾燥， $\mathrm{N}_{2}+5 \% \mathrm{H}_{2}$ の混合ガス中で $800^{\circ} \mathrm{C}, 2 \mathrm{~h}$ の仮焼による脱脂, 100 メッシュの ふるい通しを行った後, 一軸プレス0.3 $\mathrm{MPa}$ の圧力で成形し 
た。焼成は成形体を $\mathrm{Si}_{3} \mathrm{~N}_{4}-\mathrm{BN}$ 系の詰め粉中に埋没させて, $1850^{\circ} \mathrm{C}, 2 \mathrm{~h}, 0.9 \mathrm{MPa}$ の窒素雾囲気の条件下で行った。得られ た焼成体について, SEM で微構造観察を行い, Archimedes 法により気孔率を求めた。

また，気孔率の低減を目的として， $\alpha$ 窒化ケイ素（SN-E10） と種結晶をそれぞれ $50 \mathrm{vol} \%$ ずつ混合した粉末に，焼結助㶡と して $\mathrm{Y}_{2} \mathrm{O}_{3}$ （北興化学工業製 : 比表面積 $27 \mathrm{~m}^{2} / \mathrm{g}$ ） と $\mathrm{Al}_{2} \mathrm{O}_{3}$ （北 興化学工業製：比表面積 $173 \mathrm{~m}^{2} / \mathrm{g}$ ) をそれぞれ 5 mass\%， 2 mass\%添加し，上記と同じ手順で焼成体を作製した。得ら れた暁成体について, SEMにより微構造観察を行い，Archimedes 法により気孔率を求めた。

\section{3. 結果及び考察}

\section{1 種結晶の形態}

焼結助剤 3 種と比表面積の異なる $\alpha$ 窒化ケイ素 3 種を組灰 合わせて作製した種結晶の組織観察結果を図 1 に示す。図か ら, 添加した助剂成分と $\alpha$ 窒化ケイ素粉末の組み合わせの違 いにより，生成した種結晶の形態が大きく異なることが分か る。

$\mathrm{Al}_{2} \mathrm{O}_{3}$ 老添加した場合の焼成体は， $\alpha$ 窒化ケイ素粉末の比表 面積の違いに関係なく，柱状粒子はほとんど生成せず，いずれ の場合も非常に微細で, 形態は出発原料の $\alpha$ 窒化ケイ素粉末 とほとんど同じで，变化は認められなかった.

次に $\mathrm{CeO}_{2}$ を添加した場合は, 使用した $\alpha$ 窒化ケイ素粉末の 違いによって, 柱状粒子の生成量に差異が認められた。出発原 料の $\alpha$ 窒化ケイ素の比表面積が大きくなると, 異方性を持っ た粒子の生成量が増加する傾向が見られた。このことから，比 表面積が大きい $\alpha$ 窒化ケイ素を用いると異方性を持った粒子 が生成しやすくなることが考えられる，しかし，比表面積が大
きい $\alpha$ 窒化ケイ素の SN-E10 から生成した柱状粒子でも, 平 均粒子径が $0.90 \mu \mathrm{m}$ で，そのアスペクト比が 5.0 と比較的小さ

い值の種結晶しか得ることができなかった。

そして， $\mathrm{Y}_{2} \mathrm{O}_{3}$ を添加した場合は，使用した $\alpha$ 窒化ろイ素の 比表面積に関係なく，異方性を持った柱状粒子が生成した．生 成した柱状粒子の平均粒子径は SN-E03, SN-E05, SN-E10 の 順に $1.07 \mu \mathrm{m}, 1.28 \mu \mathrm{m}, 0.96 \mu \mathrm{m}$ であった。 また, 生成した柱 状粒子のアスペクト比は, 使用した $\alpha$ 窒化ケイ素の SN-E03, SN-E05, SN-E10の順に9.5, 8.6, 9.2であった. ここで, アス ペクト比の偏差を求めると, SN-E03, SN-E05, SN-E10の順 に, 4.0, 3.8, 2.7となった. 比表面積が小さい $\alpha$ 窒化ケイ素の $\mathrm{SN}-\mathrm{E} 03, \mathrm{SN}-\mathrm{E} 05$ を用いた場合の偏差が，同程度であるのに 対して, 比表面積が大きいSN-E10から作製した場合の偏差 は, SN-E03, SN-E05 を用いた場合の偏差と比べて小さく， SN-E10 から作製した種結晶のアスペクト比のバラつきが小さ くなることが分かる.

以上のことから, 比表面積の一番大きい $\alpha$ 窒化ケイ素の $\mathrm{SN}-\mathrm{E} 10$ に焼結助戍として $\mathrm{Y}_{2} \mathrm{O}_{3}$ を添加することによって，柱 状粒子のアスペクト比が大きく，そのばらつきが小さい種結晶 が得られることが分かった．今後の展開として，テープ成形法 などによる配向性の制御を考えると，アスペクト比が大きく， そのばらつきが小さい種結晶が配向性の制御に適していると考 えられるので，この組み合わせから作製した種結晶を多孔体形 成のための種結晶として選択することにした。

\section{2 多孔構造の形成}

焼結助剤を加えずに，種結晶の添加量のみを変えて作製した ときの焼成体の微構造を図 2 に示す。図から，30vol\%添加し た場合は，多孔構造の骨格を形成する柱状粒子の間に粉体が絡 みついたような組織が観察された。これは種結晶表面に存在す

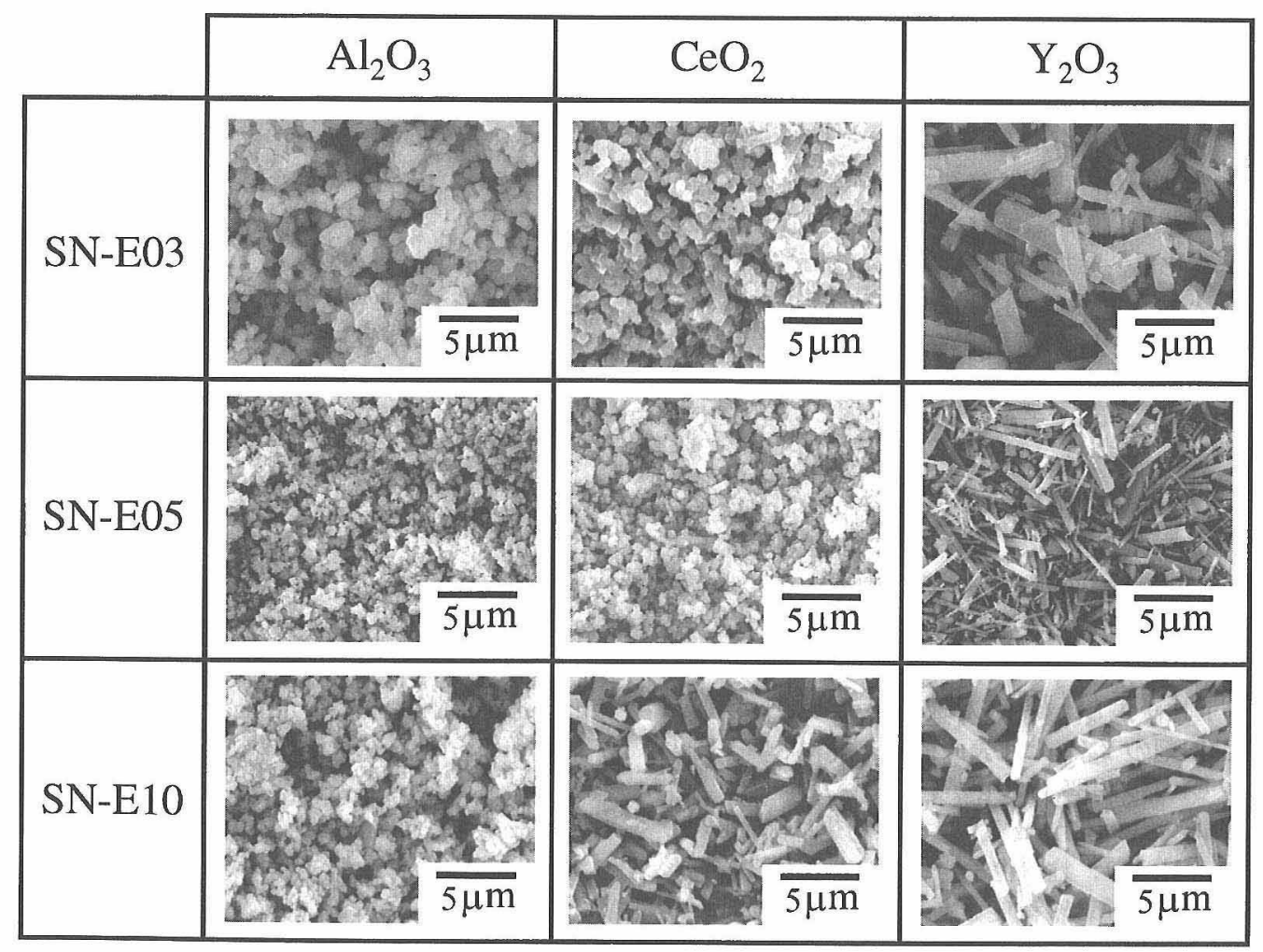

Fig. 1. Morphology of the seed crystals prepared from the powder mixture combining $\alpha$-silicon nitride powder varying specific surface area and three kind of additives $\left(\mathrm{Al}_{2} \mathrm{O}_{3}, \mathrm{CeO}_{2}\right.$ and $\left.\mathrm{Y}_{2} \mathrm{O}_{3}\right)$. 


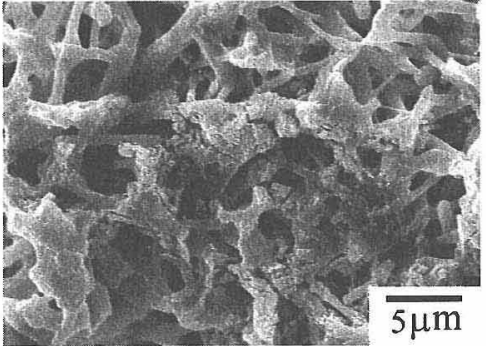

(a) Seed : 30vol\%

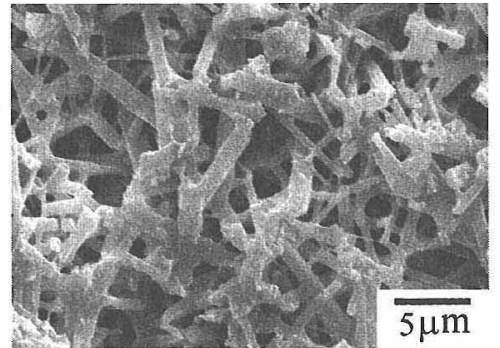

(b) Seed : 50vol\%

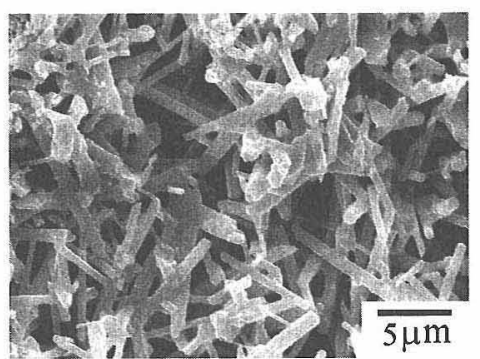

(c) Seed : 70vol\%

Fig. 2. Texture of porous body sintered by adding different amount of seed crystals with no additive. (a) Seed: $30 \mathrm{vol} \%$, (b) seed: 50 vol\% and (c) seed: 70 vol\%.

るガラス層の量では十分な液相が生成することができず，種結 晶と反応しきれなかった窒化ケイ素粉末が残存したためと考え られる. $50 \mathrm{vol} \%$ 添加した場合は粉体の残存は少なく, 柱状粒 子が良く結合して, 多孔体の骨格を形成している組織が観察さ れた.しかし，70 vol\%添加した場合は, 組織の中に多くの結 合していない柱状粒子が観察された.これは, 柱状粒子と $\alpha$ 窒化ケイ素粉末との接触量が十分でなかったことと, 柱状粒子 間の結合が促進されなかったことなどによるものと考えられ る. 以上から, 焼結助剤を添加しない条件では， $\alpha$ 窒化ケイ素 （SN-E10）に種結晶を50vol\%添加することで, 種結晶表面に 存在するガラス相によって液相が生成し，柱状粒子を主体とす る多孔構造の形成が可能であることが分かった.

また, 焼結助版を無添加の焼成体の気孔率は, 種結晶の添加 量が $30 \mathrm{vol} \%, 50 \mathrm{vol} \%, 70 \mathrm{vol} \%$ の順に, 57.5\%, 58.6\%, 60.4\% であり, 種結晶の添加量の増加に伴って気孔率がわずかに漸増 する傾向が見られた．これは種結晶のみの添加では, 液相の生 成量が不足していて，多孔体の焼結にほとんど影響を与えな かったためであると考えられる.

そこで， $\alpha$ 窒化ケイ素（SN-E10）に種結晶を50 vol\%添加 した混合粉末に, 5 mass $\% \mathrm{Y}_{2} \mathrm{O}_{3}+2$ mass $\% \mathrm{Al}_{2} \mathrm{O}_{3}$ の焼結助剂を 添加して多孔体を作製したところ, 気孔率は $36.4 \%$ と無添加の 場合に比べて大きく減少した，これは焼結助剂の添加により焼 結が進行したためであり，添加する焼結助㨈の量によって気孔 率の制御ができると考えられる. 図 3 にSEM による多孔体の 組織観察結果を示す. 図から, 柱状粒子が非常に良く結合し て, 多孔体の骨格構造を形成している組織が観察された。

\section{4. 結 論}

出発原料にウイスカーを使用しない新規の多孔構造形成プロ セスを開発することを目的として，種結晶を出発原料とするプ ロセスについて, 種結晶の作製法及び種結晶の $\alpha$ 窒化ケイ素 への添加量, 燒結助剂添加による気孔率への影響を検討し, 以 下の結果を得た.

(1) アスペクト比が大きく，そのばらつきの小さい種結晶 の作製には, 焼結助剤の $\mathrm{Y}_{2} \mathrm{O}_{3}$ と比表面積の一番大きい $\alpha$ 窒化 ケイ素粉末（SN-E10）の組み合わせが適していた.

（2）助剤を添加しない場合， $\alpha$ 窣化ケイ素粉末に50 vol\%の 種結晶を加えることにより, 柱状粒子が結合した多孔構造が形 成され, その気孔率は約 $58 \%$ 程度と比較的大きな值となっ た。

（3） $\alpha$ 窒化ケイ素粉末に50 vol\%の種結晶を加えた混合粉末

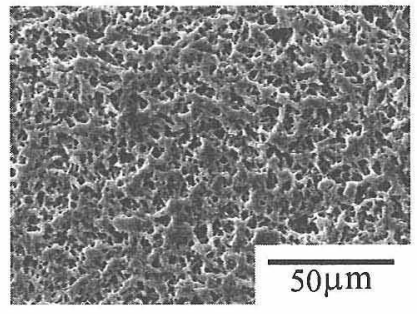

(a) low magnification

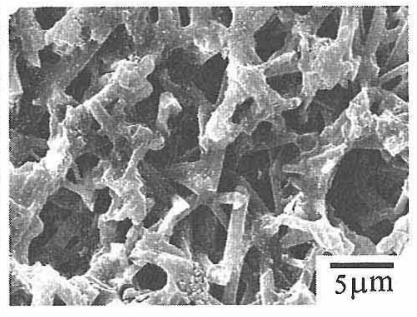

(b) high magnification

Fig. 3. Texture of porous silicon nitride synthesized from the powder mixture of 50 vol\% $\alpha$-silicon nitride powder and $50 \mathrm{vol} \%$, adding 5 mass $\% \mathrm{Y}_{2} \mathrm{O}_{3}$ and 2 mass $\% \mathrm{Al}_{2} \mathrm{O}_{3}$ as sintering aid.

(a) Low magnification and (b) high magnification

へ 5 mass $\% \mathrm{Y}_{2} \mathrm{O}_{3}+2$ mass $\% \mathrm{Al}_{2} \mathrm{O}_{3}$ の焼結助剂を添加した場 合, 焼結助剂を無添加の場合と同様の多孔構造が形成された が，焼結の進行により得られた多孔体の気孔率は約 $36 \%$ に減 少した。

謝辞 本研究は経済産業省産業技術環境局が推進する産業 技術基盤研究開発プロジェクト「シナジーセラミックスの研究開 発」の一環として、シナジーセラミックス研究体に所属する著者 らによって行われたものであり，研究の一部は本プロジェクトの 下にファインセラミックス技術研究組合が新エネルギー・産業技 術総合開発機構より委託を受けて行われたものである.

(2000年10月日本セラミックス協会第13回秋期シンポジウムに て発表)

\section{文献}

1) Shigegaki, Y., Brito, M. E., Hirao, K., Toriyama, M. and Kanzaki, S., J. Am. Ceram. Soc., 79, 2197-200 (1996).

2) Ohji, T., Shigegaki, Y., Miyajima, T. and Kanzaki, S., J. Am. Ceram. Soc., 80, 991-94 (1997).

3) Shigegaki, Y., Brito, M. E., Hirao, K., Toriyama, M. and Kanzaki, S., J. Am. Ceram. Soc., 80, 495-98 (1997).

4) Inagaki, Y., Ohji, T., Kanzaki, S. and Shigegaki, Y., J. Am. Ceram. Soc., 83, 1807-809 (2000).

5) Hirao, K., Nagaoka, T., Brito, M. E. and Kanzaki, S., J. Am. Ceram. Soc., 77, 1857-62 (1994).

6) Hirao, K., Ohashi, M., Brito, M. E. and Kanzaki, S., J. Am. Ceram. Soc., 78, 1687-90 (1995).

7) Hirao, K., Nagaoka, T., Brito, M. E. and Kanzaki, S., J. Ceram. Soc. Japan., 104, 54-58 (1996) [in Japanese].

8) Hirao, K., Tsuge, A., Brito, M. E. and Kanzaki, S., J. Ceram. Soc. Japan., 101, 1078-80 (1993). 